\title{
Pemetaan Daerah Rawan Banjir di Kabupaten Bondowoso dengan Pemanfaatan Sistem Informasi Geografis
}

\author{
(Mapping of The Flood Protected Area in Bondowoso District \\ Using Geographic Information System)
}

\author{
Nain Dhaniarti Raharjo \\ Jurusan Teknik Sipil, Politeknik Negeri Malang - Jl. Soekarno-Hatta No. 09 Kota Malang
}

\section{ARTICLE INFO}

\section{Article history}

Received : 08 February 2021

Revised : 11 Maret 2021

Accepted : 12 Maret 2021

DOI :

https://doi.org/10.33366/rekabua na.v6i1.2261

Keywords :

flood; mapping; overlay; scoring

e-mail corresponding author : nainraharjo@polinema.ac.id

\section{PENERBIT}

\section{UNITRI PRESS}

Jl. Telagawarna, Tlogomas-

Malang, 65144, Telp/Fax

0341-565500

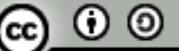

This is an open access article under the Creative Commons Attribution-ShareAlike $\quad \mathbf{4 . 0}$ International License. Any further distribution of this work must maintain attribution to the author(s) and the title of the work, journal citation and DOI. CC-BY-SA

\section{ABSTRAK}

Studi kelayakan dalam sebuah perencanaan pembangunan wilayah merupakan salah satu tahapan yang perlu dilaksanakan. Salah satu parameter dalam penentuan kelayakan pembangunan wilayah adalah keamanan daerah dari ancaman bencana. Dewasa ini, kerentanan suatu wilayah terhadap banjir menjadi sorotan utama. Kurang selektifnya pemilihan kawasan pembangunan, hingga kesalahan desain pembangunan di lapangan seringkali terjadi, hal ini diakibatkan kurangnya informasi dan kajian mengenai daerah tujuan pembangunan tersebut. Mapping area terhadap potensi bencana, salah satunya terhadap kerentanan banjir, merupakan hal yang harus ada dan perlu dilakukan dalam setiap tahap awal perencanaan pembangunan maupun pengembangan wilayah, sebagai salah satu poin dalam proses kajian studi kelayakan. Dukungan teknologi informasi dalam upaya menyediakan data real time guna keperluaan pemetaan wilayah terus berkembang pesat. Pemanfaatan teknologi Sistem Informasi Geografis (SIG) sangat diperlukan sebagai alat untuk membantu mengolah, menggabungkan, overlay, dan menyimpan berbagai data spasial maupun data non spasial. Kabupaten Bondowoso merupakan sebuah kabupaten di Jawa Timur yang akhir-akhir ini mulai giat mengembangkan wilayahnya, terutama untuk daerah pemukiman, namun terkendala dengan minimnya informasi mengenai tingkat kesesuaian lahan. Keberadaan pemetaan dan analisa wilayah rawan banjir tentu akan dapat memberikan kontribusi dalam upaya pemilihan wilayah yang tepat untuk keberlanjutan pembangunan. Salah satu instrumen penentuan tingkat kesesuaian lahan yaitu dengan menggunakan metode pengharkatan (scoring) dan proses overlay terhadap beberapa data peta tematik sebagai parameter penentu. Melalui analisis SIG tersebut diperoleh beberapa zonasi tingkat kerawanan banjir, yaitu daerah Rawan dan Aman. Luasan area yang terdefinisi sebagai daerah aman seluas $1.154 \mathrm{~km}^{2}$ $(74,10 \%)$ dan untuk daerah rawan (merah) seluas $403 \mathrm{~km}^{2}(25,889 \%)$.

\section{ABSTRACT}

A feasibility study in a regional development plan is one of the stages that need to be carried out. One of the parameters in determining the feasibility of regional development is regional security from the threat of disaster. Today, the vulnerability of a region to flooding is the main focus. Lack of selectivity in the selection of development areas, so that development design errors in the field often occur, this is due to a lack of information and studies regarding the development target areas. Mapping areas for potential disasters, one of which is flood vulnerability, is a must and needs to be done in a very early stage of development planning and regional development, as one of the points in the feasibility study review process. Information technology support to provide real-time data for regional mapping needs continues to grow rapidly. Geographical Information System (GIS) technology is needed as a tool to help the process, combine, overlay, and store various spatial and non-spatial data. Bondowoso Regency is a district in East Java that has recently begun to actively develop its territory, especially for residential areas, but is constrained by the lack of information on land suitability levels. The existence of mapping and analysis of flood-prone areas will certainly be able to contribute to efforts to select the right areas for sustainable development. One of the instruments for determining the level of land suitability is by using the scoring method and the overlay process of several thematic map data as the determining parameters. Through the GIS analysis, several zoning levels of flood hazard were obtained, namely the Prone and Safe areas. The area defined as a safe area it is $1,154 \mathrm{~km} 2(74,10 \%)$ and for the vulnerable area (red) is $403 \mathrm{~km} 2(25,889$ $\%)$.

Cara Mengutip : Raharjo, N. D. (2021). Pemetaan Daerah Rawan Banjir di Kabupaten Bondowoso dengan Pemanfaatan Sistem Informasi Geografis. Reka Buana : Jurnal Ilmiah Teknik Sipil dan Teknik Kimia, 6(1), 48-60. doi:https://doi.org/10.33366/rekabuana.v6i1.2261 


\section{PENDAHULUAN}

Pada era globalisasi saat ini, pembangunan wilayah, baik itu pemukiman maupun infrastruktur mengalami perkembangan yang begitu signifikan. Hal ini dikarenakan salah satu indikator kemajuan suatu daerah tergantung dari pesat tidaknya pembangunan. Pembangunan wilayah pemukiman maupun infrastruktur yang awalnya hanya banyak terjadi di daerah-daerah besar, saat ini juga mulai merambah ke daerah-daerah kecil sekalipun. Seiiring dengan meningkatnya pertumbuhan penduduk, meningkat pula pertumbuhan pembangunan, dan tentunya juga berakibat dengan semakin banyaknya lahan yang dibutuhkan guna menunjang keberlanjutan pemenuhan pembangunan tersebut. Terkadang, dalam proses pelaksanaan pembangunan dan tata wilayah, pihak-pihak terkait seakan lupa atau bahkan sengaja mengabaikan tentang daerah-daerah rawan, dalam hal ini khususnya mengenai daerah rawan banjir. Sehingga sering kita jumpai banyak daerah diterjang banjir.

Banjir belakangan ini sudah menjadi hal yang tidak asing lagi untuk kita. Menurut data dari bidang Geospasial BNPB, sepanjang Januari-Agustus 2020 telah terjadi bencana banjir kurang lebih sebanyak 726 di seluruh daerah di Indonesia. Banjir merupakan bencana yang mendominasi di Indonesia. Hal ini tentu berakibat fatal terhadap keselamatan masyarakat. Kurangnya informasi mengenai daerah-daerah rawan banjir juga menjadi salah satu faktor penyumbang banyaknya korban jiwa maupun materi. Kabupaten Bondowoso merupakan salah satu kabupaten kecil di Indonesia. Wilayah administrasi Kabupaten ini terdiri dari 23 wilayah kecamatan, 209 desa dan 10 kelurahan. Berdasarkan elevasi (ketinggian dari 2 permukaan laut), wilayah administrasi pada daratan tertinggi adalah Kecamatan Cermee (1.130 mdpl) dan terendah Kecamatan Prajekan (54 mdpl).

Sebesar 44,4 \% wilayah Kabupaten Bondowoso berupa daerah pegunungan dan perbukitan. Dan selebihnya yaitu sebesar 30,7 \% merupakan wilayah dataran rendah. Sedangkan untuk penggunaan lahan, mayoritas didominasi oleh sawah irigasi dan tadah hujan dengan luasan sebesar 484.967.175,198 $\mathrm{m}^{2}$. Laju pertumbuhan jumlah penduduk mengalami peningkatan rata-rata sebesar $\pm 1,33 \%$ pertahunnya (selama 5 tahun terakhir), dan selama kurun waktu 2018-2020 terjadi peningkatan alih fungsi lahan menjadi pemukiman sebesar 2,345 \% dan alih fungsi lahan menjadi wilayah industry sebesar 1,60 $\%$. [1]

Berdasarkan data-data tersebut di atas, tentu hal itu menyebabkan terjadinya banyak peningkatan rencana pembangunan pemukiman maupun industri yang dikembangkan di daerah tersebut, terlebih dengan adanya masterplan/rencana pengembangan wilayah. Dengan demikian, maka akan semakin banyak lahan yang dibutuhkan dalam mengembangkan pembangunan, dan tentunya juga diperlukan informasi secara jelas tentang daerah-daerah yang patut dipilih atau dihindari. Kriteria pemilihan lahan guna pengembangan Kawasan harus berada pada daerah yang aman dan juga jauh dari potensi bencana alam, seperti misalnya rawan banjir, bencana yang sangat dekat hubungannya dengan kehidupan masyarakat. Hal ini guna meminimalisir efek dan kerugian di kemudian hari. Oleh karenanya, ketersedian informasi dan akses data yang dapat secara mudah dan jelas akan turut membantu masyarakat dan pihak pengambil kebijakan dalam menentukan 
ke mana arah pengembangan wilayah akan dikembangkan. Secara umum, perolehan maupun penyediaan data (data acquisition) senantiasa disyaratkan memiliki kandungan informasi yang lengkap, akurat dan terbaru, sehingga hasil prosesnyapun up to date. Adanya dukungan dan perkembangan teknologi informasi maka pemanfaatan teknologi Sistem Informasi Geografis (SIG) yang berperan sebagai alat (tools) untuk mengolah, menggabungkan, meng-overlay (tumpang susun) dan menyimpan berbagai data, baik data spasial maupun data non spasial (atribut) diharapakan dapat menyajikan informasi dengan kenampakan geografis sesuai dengan yang dibutuhkan. Hasil yang diharapkan dapat berperan sebagai informasi berupa peta zonasi tingkat kerawanan banjir berdasarkan nilai scoring (pengharkatan) dari parameter data yang dominan. Berdasarkan uraian tersebut di atas, maka dalam penelitian ini, diharapkan menghasilkan informasi yang dapat dipergunakan dalam pertimbangan penggunaan wilayah untuk pembangunan berdasarkan analisis dan pembuatan peta daerah rawan banjir di Kabupaten Bondowoso, Jawa Timur. Terjadinya banjir disebabkan oleh rendahnya infiltrasi tanah, sehingga tanah tidak mampu lagi menyerap air. Selain itu banjir dapat disebabkan oleh limpasan air permukaan (runoff) yang meluap dan volumenya melebihi kapasitas pengairan system drainase atau system aliran sungai. [2]

Keberadaan teknologi berbasis system informasi geografis sangat menunjang kebutuhan Analisa wilayah. Sistem Informasi Geografis (SIG) merupakan sistem yang didukung perangkat komputer (hard ware dan soft ware) untuk mengolah, menggabungkan, proses overlay (tumpang susun) dan menyimpan berbagai macam data yang bergeoreferensi sehingga diperoleh kenampakan geografis. Definisi SIG yang lebih sederhana adalah sistem komputer yang mampu menangani dan menggunakan data untuk menjelaskan tempat/posisi di permukaan bumi. [3]

Sedangkan menurut Bernhardsen, pengertian SIG didefinisikan sebagai suatu alat/peralatan yang didesain untuk mengumpulkan, menyimpan dan menganalisis obyek dan fenomena dimana lokasi Geografis merupakan karakteristik yang sangat penting untuk dianalisis. [4]

Dalam penyelenggaraan dan pemanfaatan SIG perlu dipenuhi 5 (lima) komponen utama, yaitu:

1. Perangkat keras (hard ware)

2. Perangkat lunak (soft ware)

3. Data dan Informasi

4. Pemakai (user)

5. Produser

Di dalam proses pemetaan wilayah diperlukan adanya penggunaan metode pengharkatan (scoring) agar terbentuk skala prioritas dalam penentuan analisa wilayah. Metode pengharkatan (Scoring Method) atau pengskoran merupakan salah satu metode untuk mengevaluasi kemampuan lahan sesuai dengan tujuan aplikasinya. Pada prinsipnya metoda ini merupakan suatu cara penilaian potensi lahan dengan memberikan skor atau nilai pada masing-masing karakteristik lahan sebagai parameter sehingga dapat ditentukan kelas kemampuan lahan berdasarkan perhitungan harkatnya dari setiap parameter tersebut. Pengetrapan metode pengharkatan pada penentuan tingkat kerawanan banjir diperlukan 
klasifikasi untuk setiap parameternya. Pada dasarnaya klasifikasi ini dimaksudkan sebagai pembagian kelas untuk setiap peta tematik, sedangkan pengharkatan adalah penentuan nilai/skor pada masing-masing kelas. Klasifikasi setiap faktor atau parameter maupun skor atau nilai harkat dapat ditentukan secara subyektif, disesuaikan dengan pemanfaatan variabel tersebut dan keperluan analisis terhadap studi yang dilakukan. Dalam hal ini pemberian nilai harkat untuk setiap kelas parameter kerawanan wilayah banjir didasarkan pada kelaziman bahwa faktor pendukung yang berpotensi baik atau yang menguntungkan diberi nilai harkat tinggi, sebaliknya untuk faktor kendala atau penghambat diberi nilai harkat lebih rendah, artinya secara kwantitatif pemberian nilai harkat tersebut merupakan angka atau skor relatif. [5]

Sebagai contoh, untuk klasifikasi dan pengharkatan kemiringan lereng berdasarkan sumber data berupa peta tematik kelerengan wilayah Kabupaten Bondowoso diklasifikasikan menjadi 6 (enam), yaitu kemiringan rata-rata 0\% - 2\% (datar); 3\% - 8\% (landai); 9\% $15 \%$ (cukup landai), $16 \%$ - 25\% (cukup terjal); $26 \%$ - 40\% (terjal/curam); lebih dari $40 \%$ (sangat terjal).

Dalam hal ini, untuk klasifikasi wilayah datar diberikan nilai harkat tertinggi, sedangkan klasifikasi wilayah sangat terjal diberikan nilai harkat terendah. [6]

Prinsip metode tumpang susun (overlay method) secara kuantitatif akan menghasilkan coverage baru. Dalam overlay layer vektor, kenampakan obyek dan atributnya digabung menjadi satu dan menghasilkan layer komposit Beberapa operasi logika digunakan untuk memilih suatu area berdasarkan parameter. Pada contoh berikut ini, merupakan penggabungan secara keseluruhan poligon-poligon pada input 1 dan input 2. [7]

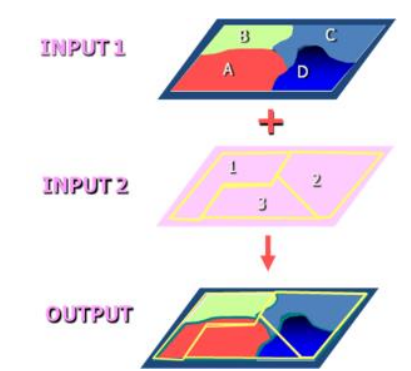

Gambar 1. Skema Proses overlay

Teknik dan metode ini mempunyai kelebihan dalam hal kecepatan pemrosesan dan kemudahan penyajian informasi, karena didukung oleh perangkat komputer (hardware dan software) yang lengkap sesuai dengan perkembangan teknologi saat ini. Perolehan dari hasil proses menggunakan teknologi SIG berupa informasi zonasi tingkat kerawanan banjir di wilayah studi.

Penelitian ini bertujuan untuk mengetahui manfaat penggunaan SIG dalam mengidentifikasi wilayah rawan banjir, menyajikan peta zonasi tingkat kerawanan banjr sebagai sarana informasi masyarakat pada daerah studi, serta mengetahui desa atau kecamatan yang berpotensi terhadap bencana banjir. Sehingga nantinya masyarakat dapat memperoleh informasi secara cepat dan tepat tentang daerah yang berpotensi rawan banjir, 
dapat mencegah atau meminimalisir dampak kerugian jiwa maupun materi pada daerah rawan banjir, dan juga dapat dijadikan dasar kebijakan dan pertimbangan dalam pengambilan keputusan bagi instansi yang terkait pengembangan kawasan industri dan pemukiman. Adapun ruang lingkup penelitian ini yaitu parameter yang digunakan adalah kemiringan lereng, ketinggian lahan/elevasi, jenis tanah, curah hujan, dan penggunaan lahan di Kabupaten Bondowoso, dan produk akhir dari penelitian ini adalah peta persebaran daerah rawan banjir di Kabupaten Bondowoso.

\section{METODE PENELITIAN}

\subsection{Obyek Penelitian.}

Obyek penelitian ini meliputi wilayah kabupaten Bondowoso.

\subsection{Bahan dan Peralatan Penelitian}

Peralatan yang digunakan dalam penelitian ini terdiri dari perangkat keras dan perangkat lunak, yaitu:

1. Peta Rupa Bumi (Topografi) kabupaten Bondowoso

2. Peta Tematik, meliputi peta Administratif, Kelerengan, Elevasi, Curah hujan dan Tataguna Lahan.

3. Data atribut (non spasial) yang terkait dengan peta peta tematik tersebut.

4. Laptop Intel Core i7 2,8 MHz RAM 8GB SSD512 GB.

5. Printer

6. Software pengolahan SIG (ArcGIS 10.2 Trial Version) dan Microsoft Office.

7. Peralatan pendukung lain, yang diperlukan.

\subsection{Metode Pelaksanaan Penelitian}

Secara umum pelaksanaan penelitian tersebut dapat dikelompokkan menjadi 3 (tiga) bagian tahapan, yaitu:

1. Tahap persiapan, pada tahap pertama ini dilakukan persiapan sebagai sarana penunjang dalam penelitian misalnya: persiapan bahan, peralatan, dan studi literatur yang berhubungan analisis menggunakan SIG.

2. Tahap pelaksanaan dan proses data, antara lain meliputi kompilasi data dan proses data awal, editing peta digital dan data atribut yang diperlukan, penggabungan data spasial dan non spasial (joint item). Data yang digunakan dalam penelitian ini hanya bersumber dari data sekunder yang berisi mengenai beberapa parameter penentuan tingkat potensi banjir di Kabupaten Bondowoso, antara lain data pertumbuhan dan sebaran penduduk di Kabupaten Bondowoso selama 10 tahun terakhir, data kelerengan (parameter 1), ketinggian (parameter 2), curah hujan (parameter 3), serta data penggunaan lahan (parameter 4). Masing-masing parameter tersebut memiliki skor berdasarkan tingkatan levelnya, yang berkorelasi dengan kerawanan terhadap potensi terjadinya banjir. Kemudian maisng-masing parameter tersebut digabungkan menggunakan metode overlay atau tumpang susun, dengan komposisi penggabungan: parameter 1 digabungkan dengan parameter 2, akan menghasilkan land unit 1, paremeter 3 digabungkan dengan parameter 4 akan menghasilkan land unit 2. 
3. Tahap hasil akhir yaitu tahap overlay akhir dengan menggabungkan hasil land unit 1 dan land unit 2 menjadi sebuah peta baru, dimana setelah terbentuk sebuah peta baru, dilakukan kompilasi antara hasil skoring masing-masing parameter dengan nilai pembobotan guna penentuan sebaran hasil zonasi potensi kerawanan banjir, dan selanjutnya dilakukan penetapan daerah rawan dan daerah aman bencana banjir wilayah studi yang dilengkapi dengan uraian pembahasan hasil dan dirangkum inti sarinya dalam simpulan penelitian. Secara sistematis rangkaian pelaksanaan penelitian dalam kaitannya dengan proses penentuan daerah rawan banjir dengan menggunakan teknologi SIG disajikan pada diagram alir berikut ini :

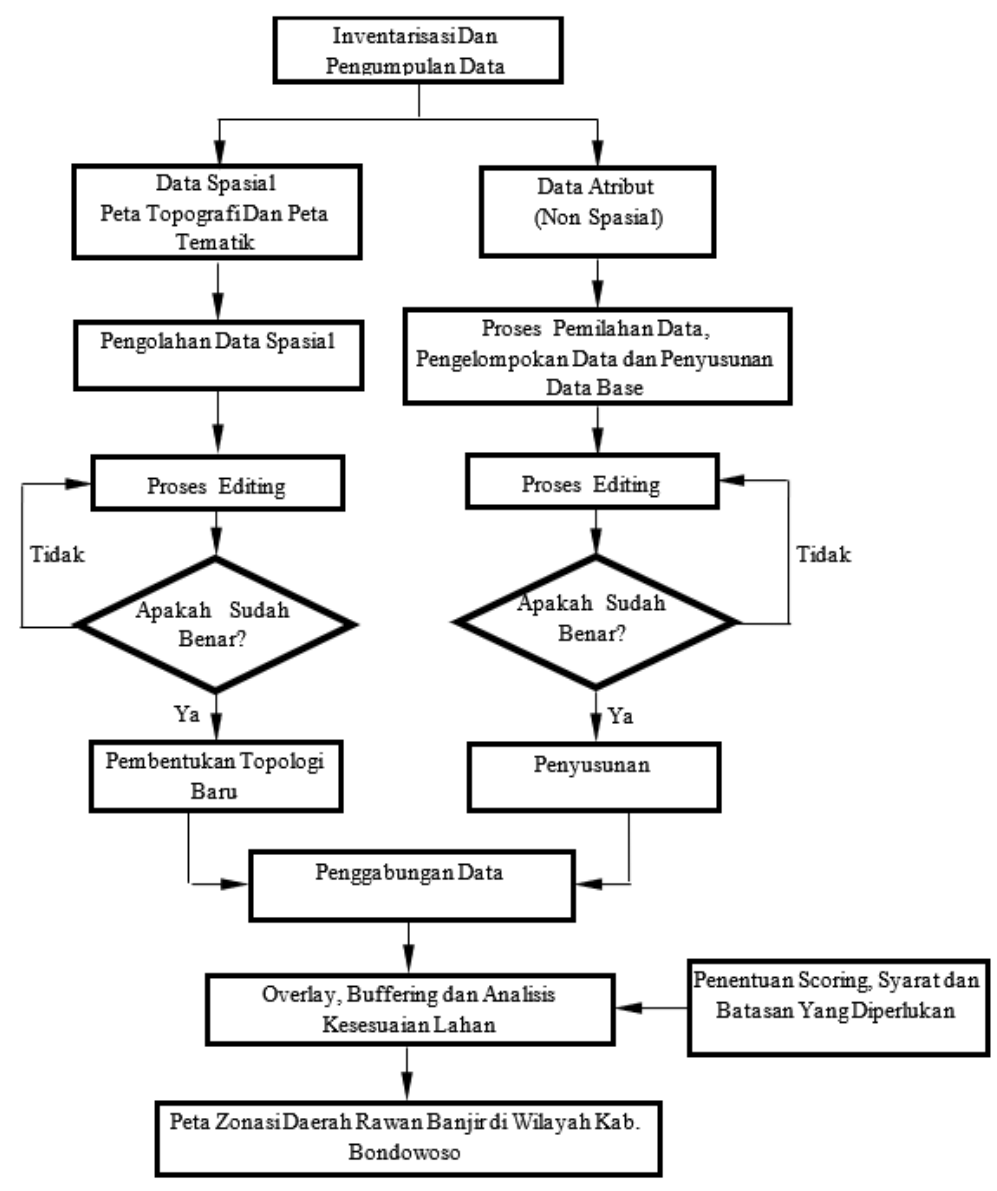

Gambar 2. Diagram Alir Penelitian

\section{HASIL DAN PEMBAHASAN}

\subsection{Skoring dan Overlay Parameter Utama}

Proses yang dilakukan pada tahap ini adalah overlay dengan metode geoprocessding, yaitu metode susun dan menggabungkan semua peta yang ada menjadi parameter banjir, dengan menggabungkan juga data atribut berupa data scoring hasil dari proses klasifikasi parameter utama, yaitu data spasial dan atribut kelerengan, elevasi, curah hujan, dan tata guna lahan. Berikut hasil klasifikasi dan scoring dari masing-masing parameter utama : 


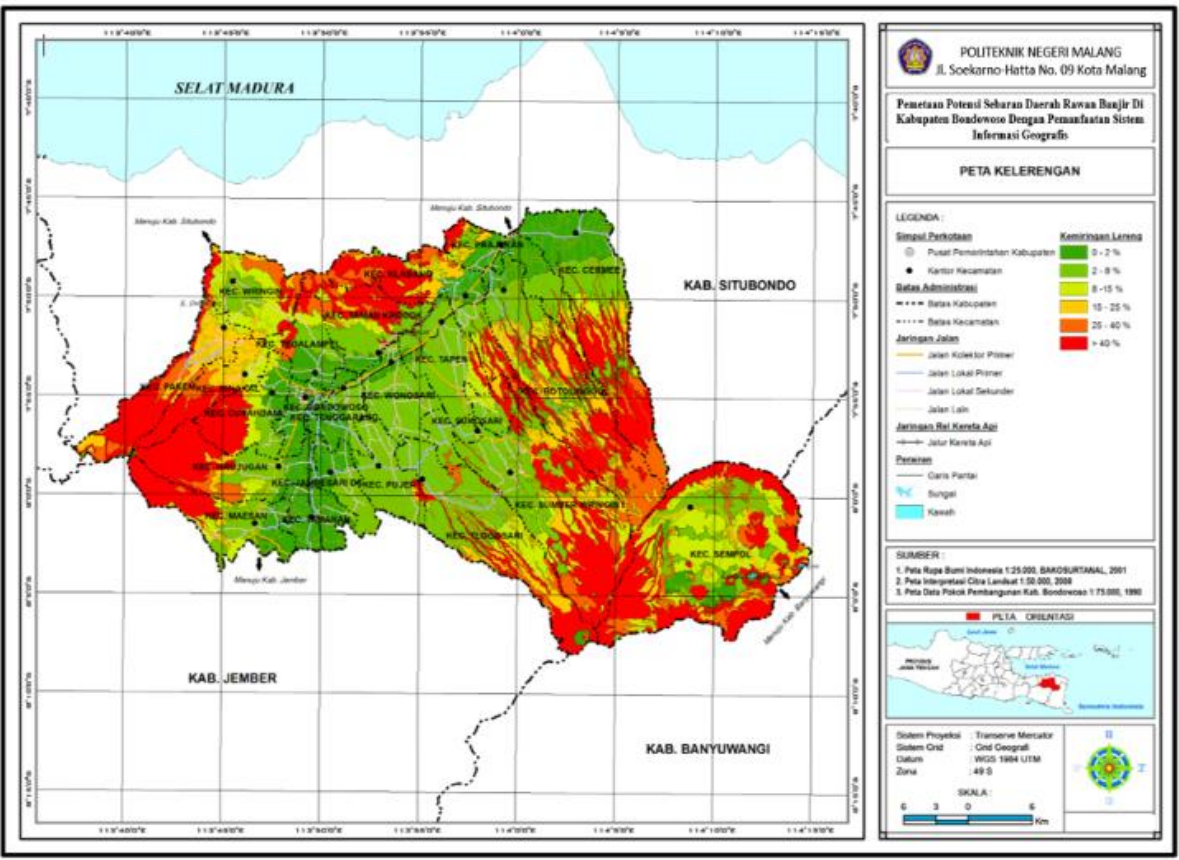

Gambar 3. Klasifikasi Lereng (Paremeter 1)

Tabel 1. Skor Klasifikasi Lereng [8]

\begin{tabular}{cccc}
\hline No. & Kemiringan Lereng (\%) & Klasifikasi & Nilai / Skor \\
\hline 1. & $>45$ & Sangat Terjal & 5 \\
2. & $25-40$ & Terjal & 10 \\
3. & $15-25$ & Cukup Terjal & 15 \\
4. & $8-15$ & Cukup Landai & 20 \\
5. & $0-8$ & Landai & 25 \\
\hline
\end{tabular}

Source: Matondang, J.P, 2013 dengan modifikasi penulis

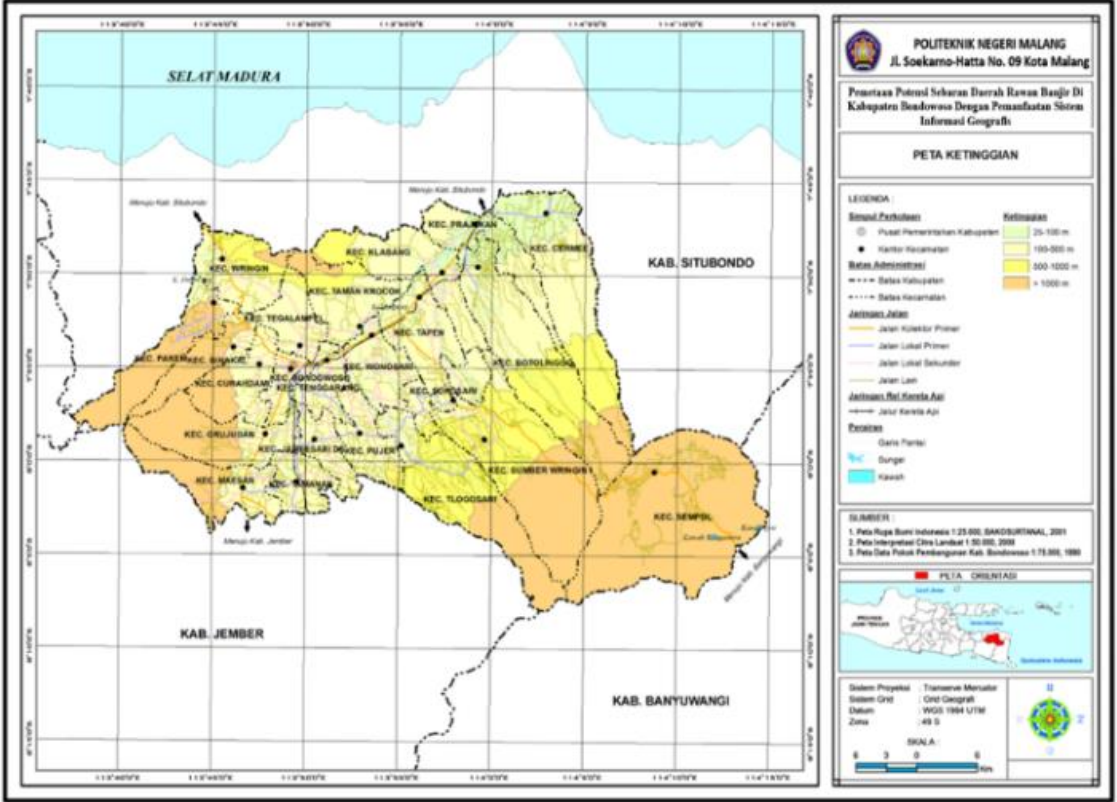

Gambar 4. Klasifikasi Ketinggian/Elevasi (Parameter 2) 
Tabel 2. Skor Hasil Klasifikasi Ketinggian [9]

\begin{tabular}{ccc}
\hline No. & Elevasi $(\mathbf{m})$ & Nilai / Skor \\
\hline 1. & $<10$ & 25 \\
2. & $10-50$ & 20 \\
3. & $50-100$ & 15 \\
4. & $100-200$ & 10 \\
5. & $>200$ & 5 \\
\hline
\end{tabular}

Source: Theml, S. 2008 dengan modifikasi penulis

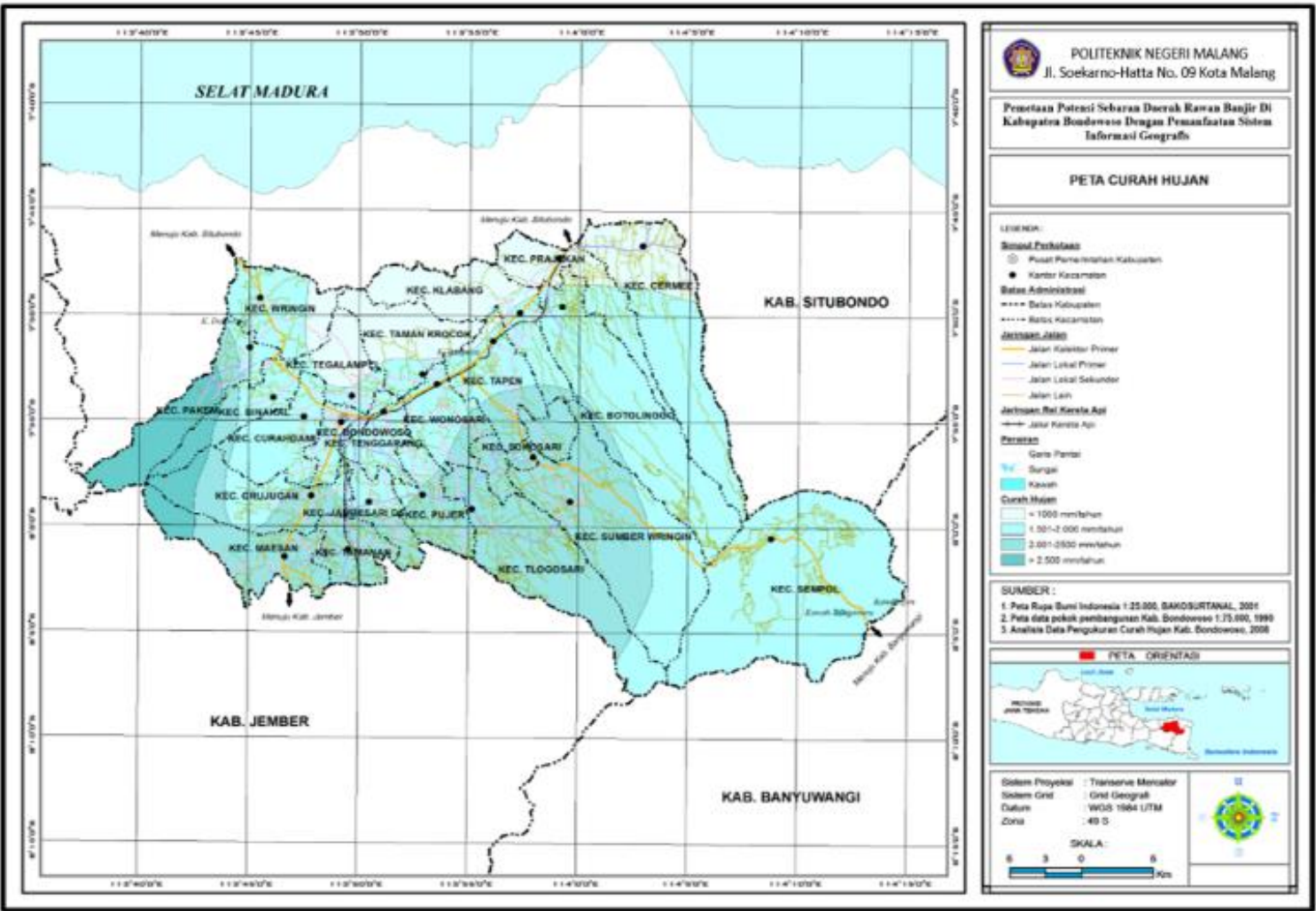

Gambar 5. Klasifikasi Curah Hujan (Parameter 3)

Tabel 3. Skor Hasil Klasifikasi Curah Hujan[9]

\begin{tabular}{cccc}
\hline No. & Rata-Rata Curah Hujan & Klasifikasi & Nilai / Skor \\
\hline 1. & $>100$ & Sangat Lebat & 25 \\
2. & $51-100$ & Lebat & 20 \\
3. & $21-50$ & Sedang & 15 \\
4. & $5-20$ & Ringan & 10 \\
5. & $<5$ & Sangat Ringan & 5 \\
\hline
\end{tabular}

Source: Theml, S. 2008 dengan modifikasi penulis 


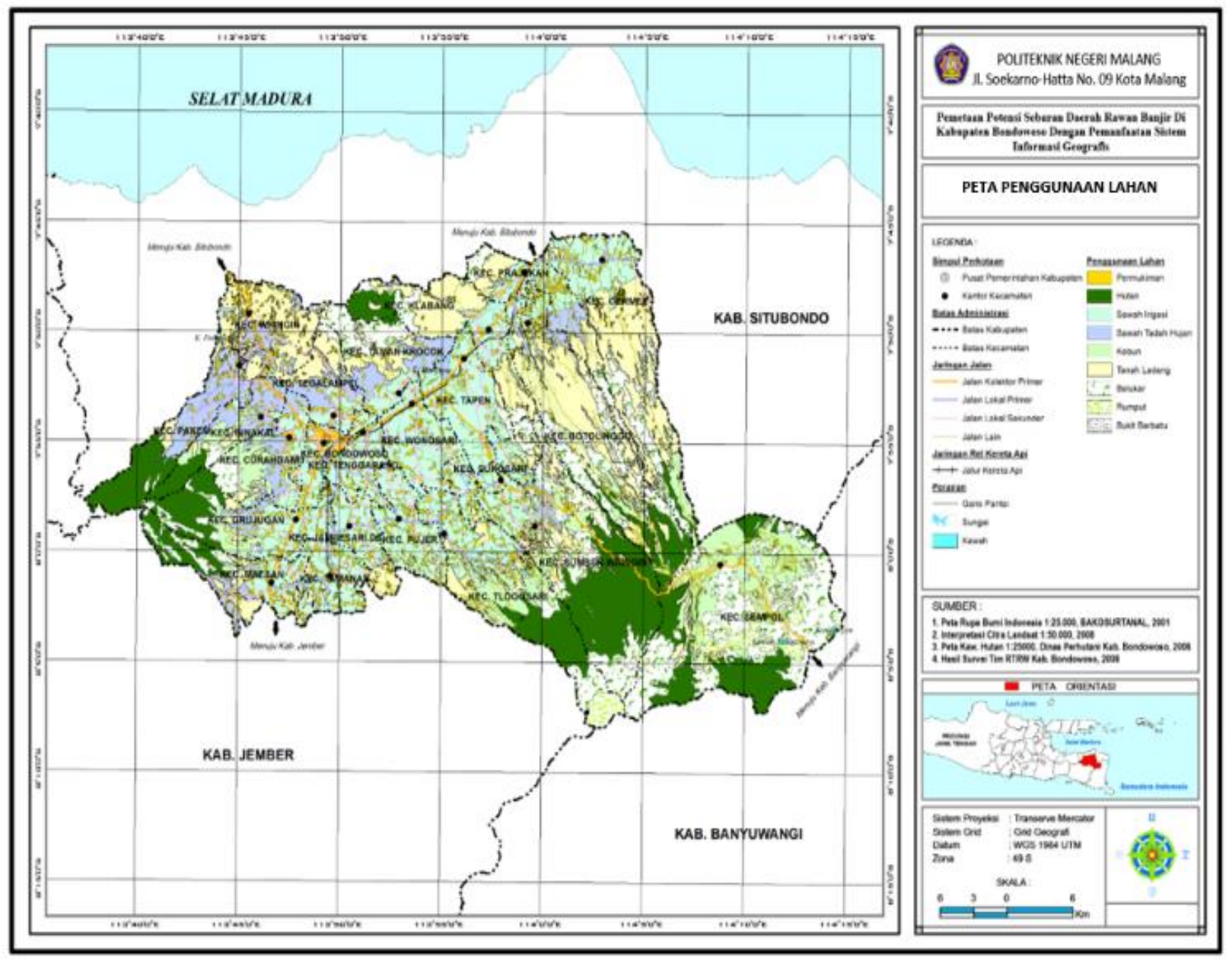

Gambar 6. Klasifikasi Penggunaan Lahan (Parameter 4)

Tabel 4. Skor Klasifikasi Penggunaan Lahan[9]

\begin{tabular}{ccc}
\hline No. & Klasifikasi & Nilai / Skor \\
\hline 1. & Hutan & 5 \\
2. & Semak Belukar & 10 \\
3. & Ladang / Tegalan / Kebun & 15 \\
4. & Sawah & 20 \\
5. & Pemukiman & 25 \\
\hline
\end{tabular}

Source: Theml, S. 2008 dengan modifikasi penulis

Hasil overlay dan pembobotan dari parameter utama ini akan menjadikan suatu parameter baru dimana gabungan beberapa peta akan membentuk suatu irisan-irisan yang dapat dijadikan parameter potensi banjir. Proses overlay antara peta kelerengan dengan peta ketinggian akan membentuk layer baru berupa unit lahan 1 (land unit 1) dan diklasifikasikan menurut hasil total skor relatifnya. 


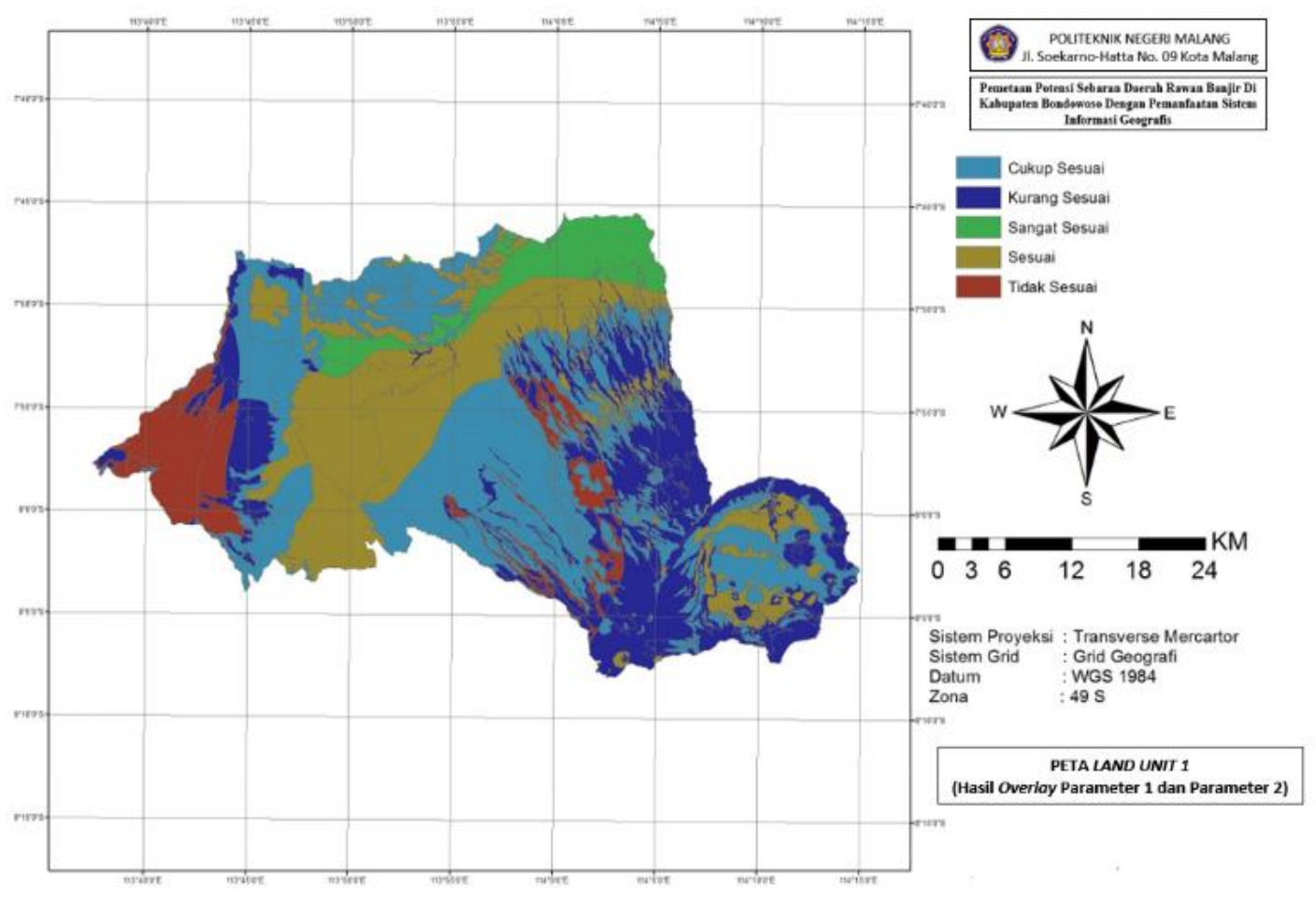

Gambar 7. Hasil Overlay Parameter 1 dan 2 (Land Unit 1)

Proses overlay berikutnya, antara peta curah hujan dengan peta tata guna lahan akan menghasilkan layer baru berupa unit lahan 2 (land unit 2) yang juga diklasifikasikan menurut hasil total skor relatifnya.

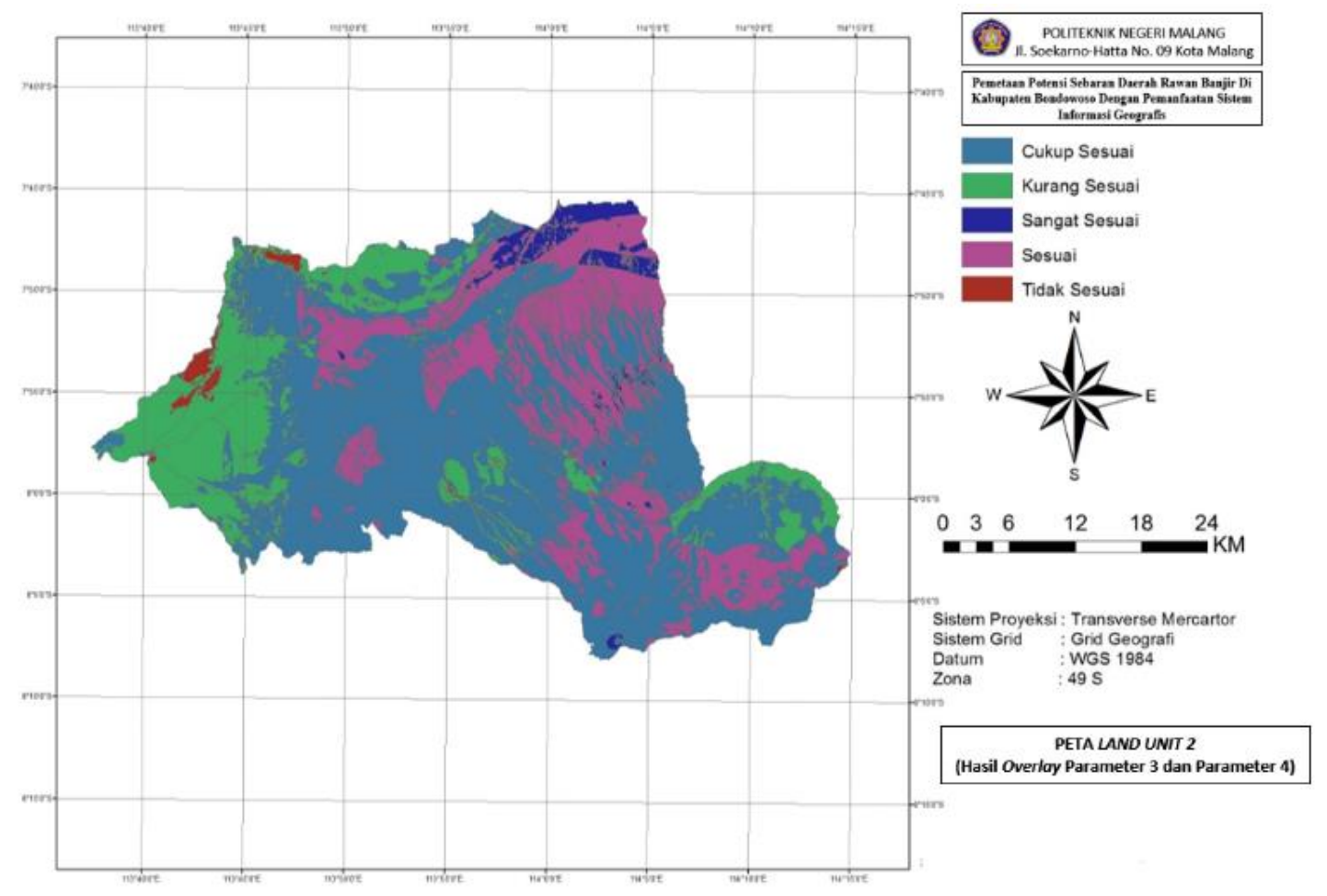

Gambar 8. Hasil Overlay Parameter 3 dan 4 (Land Unit 2) 
Hasil klasifikasi unit lahan 1 dan unit lahan 2 tersebut keduanya dilakukan overlay lagi sehingga membentuk layer baru disebut sebagai unit lahan 3 (land unit 3) yaitu peta akhir. Untuk menentukan nilai dari parameter yang baru maka diperlukan suatu persamaan matematis dengan cara menggabungkan antara skoring dan pembobotan yang telah dilakukan sebelumnya, dengan menggunakan persamaan empiris berikut ini:

$$
X=\sum_{i=1}^{n}(W i \cdot X i)
$$

Keterangan:

$\mathrm{X}=$ Nilai kerawanan

$\mathrm{Wi}=$ Bobot untuk parameter ke-i

$\mathrm{Xi}=$ Skor kelas pada parameter ke- $\mathrm{i}$

Nilai bobot untuk masing-masing parameter ditetapkan sebagai berikut:

Tabel 5 Bobot di Masing-Masing Parameter Utama [10]

\begin{tabular}{ccc}
\hline No. & Parameter & Bobot \\
\hline 1. & Kelerengan & 0,20 \\
2. & Ketinggian & 0,10 \\
3. & Curah Hujan & 0,15 \\
4. & Tata Guna Lahan & 0,15 \\
\hline
\end{tabular}

Source:Primayuda (2006) dalam Purnama A, (2008), dengan modifikasi penulis

Sehingga dari pembobotan parameter dan persamaan tersebut kita bisa menentukan nilai standar untuk memberi skor pada peta yang baru. Dalam peta baru ini nilai skor ditentukan berdasarkan dimana wilayah dengan potensi banjir yang tinggi akan memiliki nilai yang tinggi, dengan menggunakan 3 klasifikasi kerentanan, yaitu Sangat Rawan, Rawan, dan Aman dengan mengacu pada nilai/skor tingkat kerawanan banjir.

\subsection{Hasil Analisa SIG}

Dari proses analisa SIG menggunakan metode scoring dan juga pembobotan, tingkat kerawanan direncanakan terbagi menjadi 3 kategori, yaitu Aman dengan skor 0 - 1,5. Rawan dengan skor 1,5 - 3,5. Dan kategori Sangat Rawan dengan skor 3,5 - 5. Namun, hasil dari penggabungan scoring dan pembobotan untuk parameter utama di wilayah Kabupaten Bondowoso, hanya diperoleh hasil 2 parameter tingkat kerawanan, yaitu daerah aman (hijau) dan daerah rawan (merah). Daerah untuk tingkat rawan terhitung seluas 403 $\mathrm{km}^{2}$ dan untuk daerah aman seluas $1.154 \mathrm{~km}^{2}$. Berikut hasil pemetaan daerah potensi banjir di Kabupaten Bondowoso. 


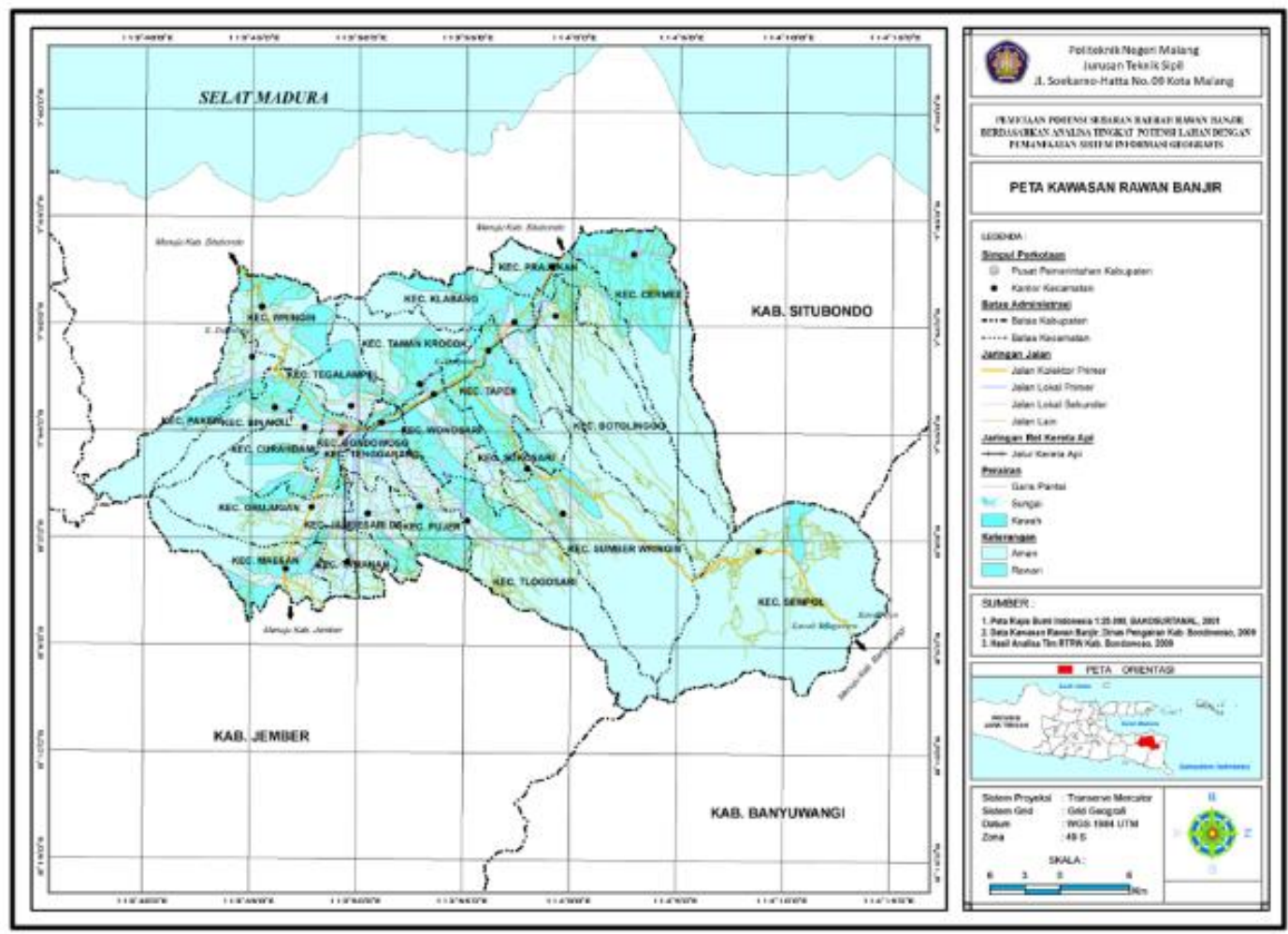

Gambar 9. Peta Sebaran Daerah Rawan Banjir di Wilayah Kab. Bondowoso

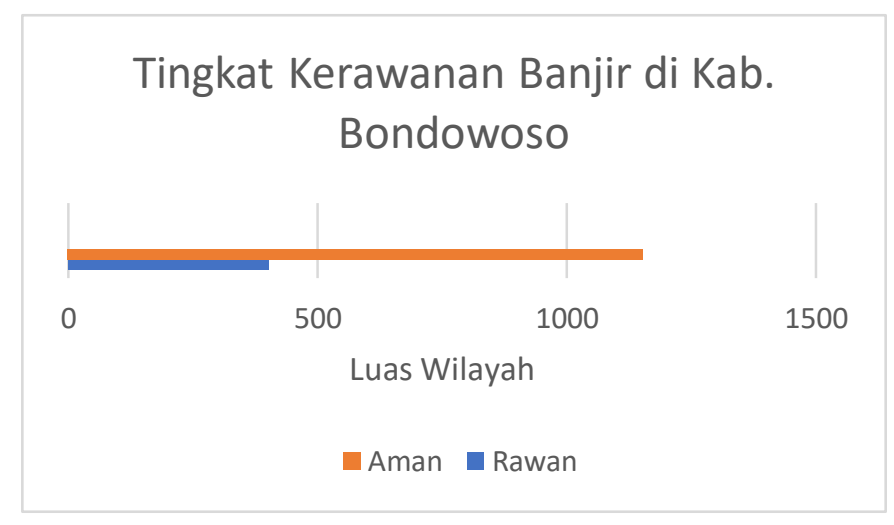

Gambar 10. Grafik Luas Wilayah Berdasarkan Tingkat Kerawanan Terhadap Banjir

\section{KESIMPULAN}

Kabupaten Bondowoso termasuk kabupaten yang memiliki potensi tidak terlalu banyak daerah rawan banjir. Hal ini tampak dari hasil yang diperoleh dari analisa skoring dan pembobotan, dimana hanya muncul 2 parameter yakni daerah Rawan dan Aman. Zona hijau atau kawasan yang aman (ditandai dengan warna biru terang pada peta) adalah lahan yang secara teknis sangat berperan baik sebagai daerah resapan air. Pada umumnya lahan tersebut relatif memiliki nilai kelerengan cukup curam dengan nilai $25-45 \%$, dengan nilai ketinggian >100 meter, dan ditunjang tutupan lahan yang masih terjaga dengan kondisi serapan air yang masih maksimal. Zona merah adalah kawasan rawan (ditandai dengan warna biru tosca pada peta), dimana lahan secara teknis tidak berpotensi baik sebagai 
daerah resapan air dan daerah pengembangan pembangunan. Pada umumnya kondisi tersebut ditunjukkan oleh lahan yang mempunyai kemiringan cukup landau yaitu $<2 \%$ dengan intensitas curah hujan yang tinggi, nilai ketinggiannya berada pada level $<60$ meter, dan tutupan lahan yang sudah banyak mengalami perubahan/alih fungsi lahan. Luasan area yang terdefinisi sebagai daerah aman seluas $1.154 \mathrm{~km}^{2}$ atau sebesar $74,10 \%$. Dan untuk daerah rawan (merah) adalah seluas $403 \mathrm{~km}^{2}$ atau sebesar 25,889\%.

\section{DAFTAR PUSTAKA}

[1] "BPS Kabupaten Bondowoso." https://bondowosokab.bps.go.id/publication/2020/04/27/88287063aeaae78738abbda 5/kabupaten-bondowoso-dalam-angka-2020.html (accessed Mar. 10, 2021).

[2] N. Nuryanti, J. L. Tanesib, and A. Warsito, "Pemetaan Daerah Rawan Banjir dengan Penginderaan Jauh dan Sistem Informasi Geografis di Kecamatan Kupang Timur Kabupaten Kupang Provinsi Nusa Tenggara Timur," J. Fis. Fis. Sains dan Apl., vol. 3, no. 1, pp. 73-79, 2018.

[3] Aronoff-Stanley, "Remote Sensing Technology Transfer in Environmental Management: Application ... - Stanley Aronoff - Google Buku," WDL Publication, 1989. https://books.google.co.id/books?id=pkjxAAAAMAAJ\&dq=aronoff 1989\&hl=id\&source=gbs_similarbooks (accessed Feb. 08, 2021).

[4] Bernhardsen-Tor, "Geographic Information Systems: An Introduction - Tor Bernhardsen - Google Buku," Wiley; 3rd edition, 2002. https://books.google.co.id/books?id=e-yvDHkDLJQC\&dq=aronoff 1989\&hl=id\&source=gbs_similarbooks (accessed Feb. 08, 2021).

[5] S. R. . Sitorus, "Perencanaan Penggunaan Lahan - Santun R.P. Sitorus - Google Buku," Bogor : IPB Press, 2017. https://books.google.co.id/books?id=0ioTEAAAQBAJ\&printsec=frontcover \&dq=sit orus+evaluasi+sumberdaya+lahan \&hl=id\&sa=X\&ved=2ahUKEwii9uz95dnuAhVG b30KHesiCAAQ6AEwAHoECAYQAg\#v=onepage $\& \mathrm{q}=$ sitorus evaluasi sumberdaya lahan \&f=false (accessed Feb. 08, 2021).

[6] K. Darmawan and A. Suprayogi, "Analisis tingkat kerawanan banjir di kabupaten sampang menggunakan metode overlay dengan scoring berbasis sistem informasi geografis," J. Geod. Undip, vol. 6, no. 1, pp. 31-40, 2017.

[7] V. Y. Iskhak and M. D. Putra, "Pemetaan Wilayah Potensi Rawan Bencana Banjir Berbasis Sistem Informasi Geografis," J. Geomaritim Indones. (Indonesian J. Geomaritime), vol. 1, no. 2, 2019.

[8] J. P. Matondang, S. Kahar, and B. Sasmito, “Analisis Zonasi Daerah Rentan Banjir Dengan Pemanfaatan Sistem Informasi Geografis (Studi Kasus : Kota Kendal Dan Sekitarnya)," J. Geod. Undip, vol. 2, no. 2, 2013.

[9] M. Darmawan and S. Theml, "Katalog Methodologi Penyusunan Peta Geo Hazard Dengan GIS," Banda Aceh, 2008.

[10] A. Primayuda, "Pemetaan Daerah Rawan dan Resiko Banjir Menggunakan Sistem Informasi Geografis,” Inst. Pertan. Bogor, Bogor, 2006. 
